\title{
Influence of Support on Catalytic Activity of Nano-Ni Catalysts in P-nitrophenol Reduction to P-aminophenol
}

\author{
I. Sarhan, T. El-Essawy, A. El-Bellihi and M.M. Selim* \\ Dept. Chem. Faculty of Science, Banha University, Banha and \\ *Dept. Phys Chem. National Research Center, Cairo, Egypt.
}

\begin{abstract}
7 THE CATALYTIC activities of $\mathrm{CaCO}_{3^{-}}, \mathrm{TiO}_{2^{-}}, \mathrm{Al}_{2} \mathrm{O}_{3}$ - and $\mathrm{SiO}_{2^{-}}$ supported $\mathrm{Ni}$ catalysts in reduction of $\mathrm{p}$-nitrophenol to $\mathrm{p}$ aminophenol were investigated. The catalysts were prepared by impregnation using a solution of appropriate concentrations of $\mathrm{NiCl}_{2}$ in order to obtain catalysts with $2.5,5$ and $10 \%$ nickel. The dried solids were treated with hydrazine hydrate to reduce nickel ions to metallic nickel, on which the reduction of p-nitrophenol takes place. The catalysts were characterized by XRD and SEM before and after conducting the reduction reaction of p-nitrophenol .The results showed that all catalysts contain crystalline nano nickel. The catalysts were active in reduction of p-nitrophenol into p-aminophenol. The activity was in the following order: $\mathrm{Ni} / \mathrm{TiO}_{2}>\mathrm{Ni} / \mathrm{CaCO}_{3}>\mathrm{Ni} / \mathrm{SiO}_{2}>$ $\mathrm{Ni} / \mathrm{Al}_{2} \mathrm{O}_{3}$, i.e. the activity was decreased with increasing the acidity of the supports.
\end{abstract}

Keywords: p-Nitrophenol, p-Aminophenol, Catalytic reduction, Nano-sized nickel, Hydrazine hydrate and Supports.

P-aminophenol is an important intermediate in the manufacture of pharmaceuticals such as paracetamol, acetanilide, phenacetin ...,etc ${ }^{(1-7)}$. Paminophenol is also used as a photographic developer, corrosion inhibitor and as a dyeing agent ${ }^{(8)}$. Due to the significance of $p$-aminophenol, there is a demand for direct catalytic reduction of $\mathrm{p}$-nitrophenol. Conventionally, $\mathrm{p}$-aminophenol is produced by iron-acid reduction of p-nitrophenol ${ }^{(9)}$. The major disadvantage of the iron-acid reduction process is the generation of large amount of $\mathrm{Fe}-\mathrm{FeO}$ sludge $\left(1.2 \mathrm{~kg} / \mathrm{kg}\right.$ product) which causes a serious pollution problem ${ }^{(2)}$. Now the production of $\mathrm{p}$-aminophenol is mainly via a single step catalytic hydrogenation of nitrobenzene using both noble metal $(\mathrm{Pt})$ and strong mineral acid $\left(\mathrm{H}_{2} \mathrm{SO}_{4}\right)$ as co-catalysts ${ }^{(2,3)}$. The disadvantages of this process are that strong corrosive sulphuric acid and high cost noble metal are used and that aniline as a competitive byproduct is largely and unavoidably formed.

Direct reduction of p-nitrophenol catalyzed by $\mathrm{Pt}, \mathrm{Pd}, \mathrm{Ru}$ and $\mathrm{Ni}$ is considered as an alternative green process for the production of $\mathrm{p}$-aminophenol ${ }^{(3,4)}$. It is well known that nickel is an active and facile catalyst in reduction reaction. However, commercially available Raney Ni catalyst not only catalyzes the reduction of

*Corresponding author e-mail: mmasliim@yahoo.com 
nitro group to amino one but also catalyzes the hydrogenation of aromatic ring, perhaps caused by the micropores of Raney $\mathrm{Ni}^{(3)}$. In contrast to Raney $\mathrm{Ni}$ catalyst, active metallic nickel present in supported catalysts usually exists in the style of nanosized crystallites, avoiding formation of micropore structure.

However, the nature of support affects the performance of active phase, especially for nickel where metal-support interactions are involved ${ }^{(10-16)}$. The catalytic performance of supported $\mathrm{Ni}$ catalyst in reduction of $\mathrm{p}$-nitrophenol to $\mathrm{p}$ aminophenol is seldom investigated. In our previous works we studied the reduction of p-nitrophenol over nano nickel on different supports ${ }^{(12-16)}$.

In our present work, $\mathrm{CaCO}_{3^{-}}, \mathrm{TiO}_{2^{-}}, \mathrm{Al}_{2} \mathrm{O}_{3^{-}}$, and $\mathrm{SiO}_{2}$-supported $\mathrm{Ni}$ catalysts were prepared by incipient wetness impregnation method. The supported $\mathrm{Ni}$ catalysts were characterized by Scanning Electron Microscope and X-ray diffraction techniques. The influence of support on the catalytic activity of $\mathrm{Ni}$ in reduction of p-nitrophenol to p-aminophenol was investigated.

\section{Experimental}

\section{Catalyst preparation}

Silica support preparation

Dilute commercial sodium silicate solution was treated with dilute $\mathrm{HCl}$ until pH 6.5 at which complete precipitation of silica occurred. The precipitated silica was filtered, washed, dried and calcined at $550{ }^{\circ} \mathrm{C}$ for $2 \mathrm{hr}$.

\section{$\mathrm{Al}_{2} \mathrm{O}_{3}$ preparation}

The $\mathrm{Al}_{2} \mathrm{O}_{3}$ was prepared from $\mathrm{Al}$-salt by precipitation with ammonia solution with heating and washing the obtained precipitate. The solid was dried and calcined at $550{ }^{\circ} \mathrm{C}$ for $2 \mathrm{hr}$.

Supported catalysts

All catalysts were prepared by impregnation of the supports with appropriate quantity of $\mathrm{NiCl}_{2}$ solutions in order to obtain $2.5,5$ and $10 \mathrm{wt} \% \mathrm{Ni}$ on the supports.

The final catalysts preparations are:

TABLE 1. Final catalyst preparations.

\begin{tabular}{|c|c|c|c|}
\hline Support & \multicolumn{3}{|c|}{ Catalysts } \\
\hline Unsupported Ni & \multicolumn{3}{|c|}{} \\
\hline $\mathrm{TiO}_{2}$ & $2.5 \% \mathrm{Ni} / \mathrm{TiO}_{2}$ & $5 \% \mathrm{Ni} / \mathrm{TiO}_{2}$ & $10 \% \mathrm{Ni} / \mathrm{TiO}_{2}$ \\
\hline $\mathrm{CaCO}_{3}$ & $2.5 \% \mathrm{Ni} / \mathrm{CaCO}_{3}$ & $5 \% \mathrm{Ni} / \mathrm{CaCO}_{3}$ & $10 \% \mathrm{Ni} / \mathrm{CaCO}_{3}$ \\
\hline $\mathrm{SiO}_{2}$ & $2.5 \% \mathrm{Ni} / \mathrm{SiO}_{2}$ & $5 \% \mathrm{Ni} / \mathrm{SiO}_{2}$ & $10 \% \mathrm{Ni} / \mathrm{SiO}_{2}$ \\
\hline $\mathrm{Al}_{2} \mathrm{O}_{3}$ & $2.5 \% \mathrm{Ni} / \mathrm{Al}_{2} \mathrm{O}_{3}$ & $5 \% \mathrm{Ni} / \mathrm{Al}_{2} \mathrm{O}_{3}$ & $10 \% \mathrm{Ni} / \mathrm{Al}_{2} \mathrm{O}_{3}$ \\
\hline
\end{tabular}

Egypt. J. Chem. 57, No. 1 (2014) 


\section{Reduction of the catalysts}

All the prepared solids were reduced by the addition of hydrazine hydrate and few drops of concentrated sodium hydroxide and heating the mixture at $80^{\circ} \mathrm{C}$ until the color of the mixture turned black or grayish black, indicating complete reduction of nickel ions into nano nickel metals.

Characterization of the prepared and reduced catalysts

$X R D$ : X-Ray diffraction patterns were done using Bruker D8 advance instrument with $\mathrm{CuK} \alpha$ target with secondly monochromator $40 \mathrm{kV}, 40 \mathrm{~mA}$.

Scanning Electron Microscopy: The scanning electron microscope (SEM) photographs were carried out using SEM Model Philips XL 30 attached with EDX unite, with accelerating voltage $30 \mathrm{k}$. magnification $10 \mathrm{x}$ up to $400.000 \mathrm{x}$ and resolution for W. $(3.5 \mathrm{~nm})$. The samples were coated with gold.

Catalytic activity procedure: The process of reduction of p-nitrophenol into p-aminophenol was carried out as follows:

$1 \mathrm{~g}$ of the reduced catalyst was taken with $10 \mathrm{ml}$ of hydrazine hydrate and few drops of sodium hydroxide. To this mixture a solution of $0.5 \mathrm{~g} \mathrm{p}$-nitrophenol in $5 \mathrm{ml}$ methanol was added. The mixture was heated at $80^{\circ} \mathrm{C}$ with stirring until the color is turned from yellow to colorless, indicating complete reduction of $\mathrm{p}$ nitrophenol. This time was taken as a measure for the activity of the catalyst, i.e the small time indicating the high activity.

\section{Results and Discussion}

In this work the effect of the support on the catalytic activity of nickel catalysts in reduction of p-nitrophenol into p-aminophenol was conducted. The catalysts were characterized using $\mathrm{X}$-ray analysis and scanning electron microscopy.

\section{$X R D$ analysis}

$\left(2.5 \mathrm{wt} \% \mathrm{Ni} / \mathrm{TiO}_{2}\right.$ gave no detectable XRD patterns for crystalline nickel due to the small amount of nickel.)

Figures 1-4 illustrate the obtained results of X-ray data.

Figure 1a shows the XRD of $5 \% \mathrm{Ni} / \mathrm{TiO}_{2}$ which gave the XRD patterns of nanonickel crystallites. This figure shows also the crystalline $\mathrm{TiO}_{2}$ phase. Figure $1 \mathrm{~b}$ shows the catalyst after reaction in which the degree of crystallinity of nano nickel decreased.

Figure 2(a) shows the XRD of the reduced $5 \% 5 \% \mathrm{Ni} / \mathrm{SiO}_{2}$; from this figure, it can be shown that no patterns for $\mathrm{SiO}_{2}$ were detected, i.e. it is an amorphous phase, but only a crystalline nanonickel metal was obtained. The participation of the catalyst in the reduction of p-nitrophenol led to sharp decrease in the crystallinity of nickel metal Fig. 2 (b). This confirms the idea about the formation of unstable intermediate complex of nickel with the reacting compound leading to a considerable change in the crystallinity of the crystalline nano nickel. 
Figure 3(a) shows the patterns of the catalyst prepared with $5 \% \mathrm{Ni} / \mathrm{Al}_{2} \mathrm{O}_{3}$. The inspection of the X-ray data of this catalyst, nanonickel crystalline metallic phase was detected with amorphous $\mathrm{Al}_{2} \mathrm{O}_{3}$ phase. Figure $3(\mathrm{~b})$ shows the $\mathrm{X}$-ray data of nickel on aluminium oxide which illustrates the existence of crystalline nickel with somewhat less degree of crystallinity on the amorphous alumina.

Figure 4(a) shows the patterns of the catalyst with $5 \% \mathrm{Ni} / \mathrm{CaCO}_{3}$. From this figure, it can be observed that nanonickel crystalline metallic phase was obtained with well crystalline $\mathrm{CaCO}_{3}$ phase. Figure 4 (b) showed a considerable decrease in the degree of crystallinity of nickel while a somewhat retaining the crystallinity of calcium carbonate. This is also a confirmation for the participation of the active nickel in the process of reaction as an intermediate complex and converting into less crystalline phase .

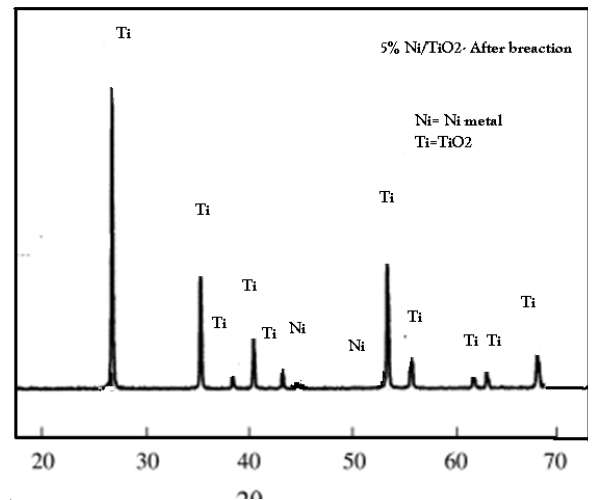

Fig. 1. (a)The representative XRD patterns of $5 \% \mathrm{TiO}_{2}$ - supported $\mathrm{Ni}$ catalyst before reaction.

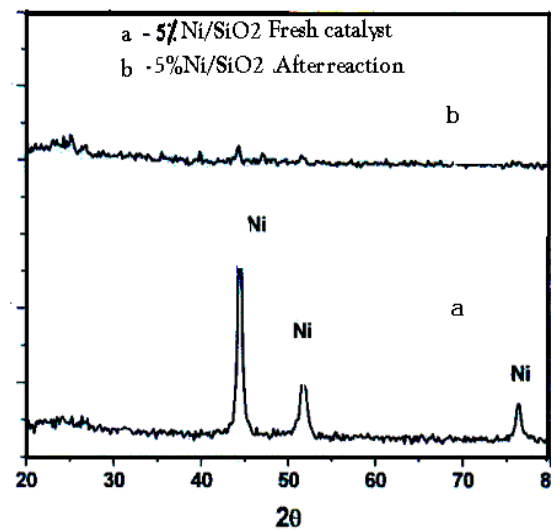

Fig. 2.The representative $\mathrm{XRD}$ patterns of $5 \% \mathrm{SiO}_{2^{-}} \quad \mathrm{Al}_{2} \mathrm{O}_{3^{-}}$supported $\mathrm{Ni}$ catalyst before and after reaction .

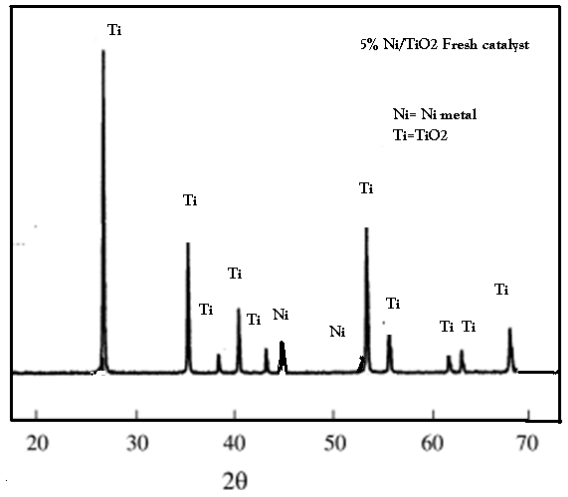

Fig. 1.(b)The representative XRD patterns of $5 \% \mathrm{TiO}_{2}$ - supported $\mathrm{Ni}$ catalyst after reaction .

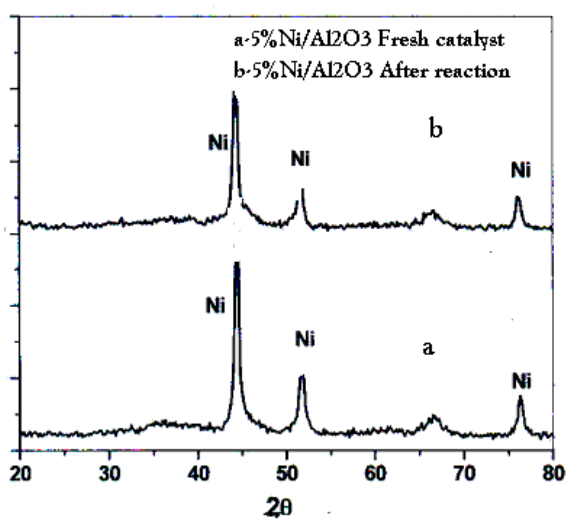

Fig. 3. The representative XRD patterns of $5 \%$ supported $\mathrm{Ni}$ catalyst before and after reaction .

Egypt. J. Chem. 57, No. 1 (2014) 


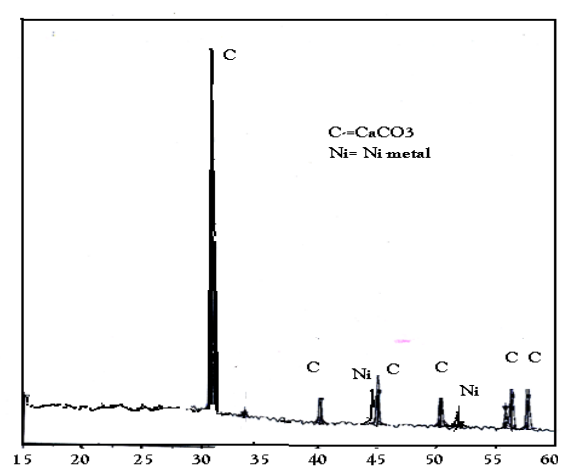

Fig. 4.(a)The representative XRD patterns of $5 \% \mathrm{CaCO}_{3}^{-}$supported $\mathrm{Ni}$ catalyst before reaction

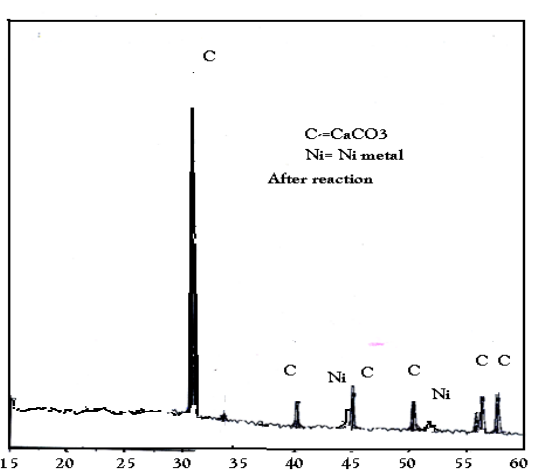

Fig. 4.(b)The representative XRD patterns of $5 \% \mathrm{CaCO}_{3}$ - supported Ni catalyst after reaction .

Scanning electron microscopy

The SEM data are illustrated in Fig. 5-12.

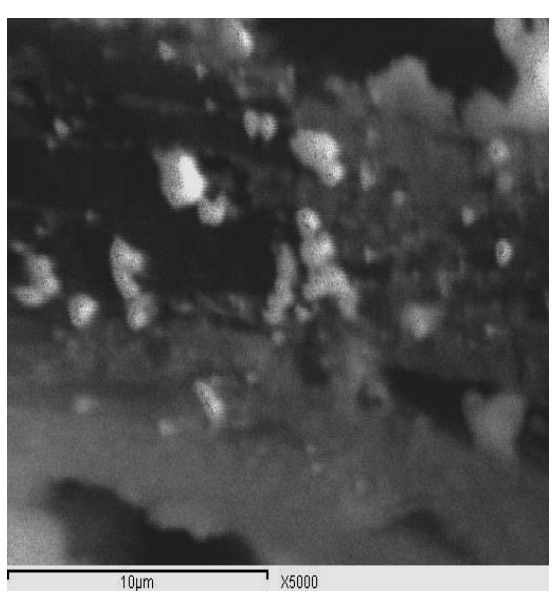

Fig. 5. Scanning electron micrograph of $5 \% \mathrm{Ni} /$ $\mathrm{CaCO}_{3}$ before addition of p-nitropheno

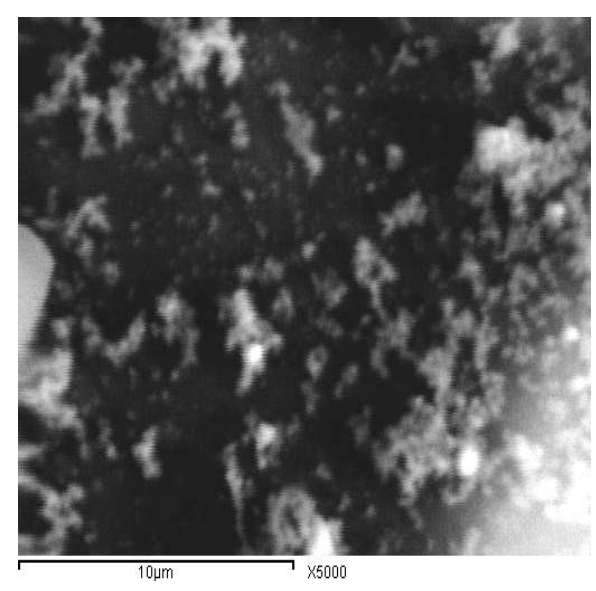

Fig. 6. Scanning electron micrograph of $5 \% \mathrm{Ni} /$ $\mathrm{CaCO}_{3}$ after addition of p-nitrophenol.

\section{Reduction of p-nitrophenol}

In this series of experiments one gram of the catalyst was firstly reduced using hydrazine hydrate as hydrogen donor with drops of sodium hydroxide. The reduction of nickel ions in solution was completed when the color of the solution becomes black or grayish black. 

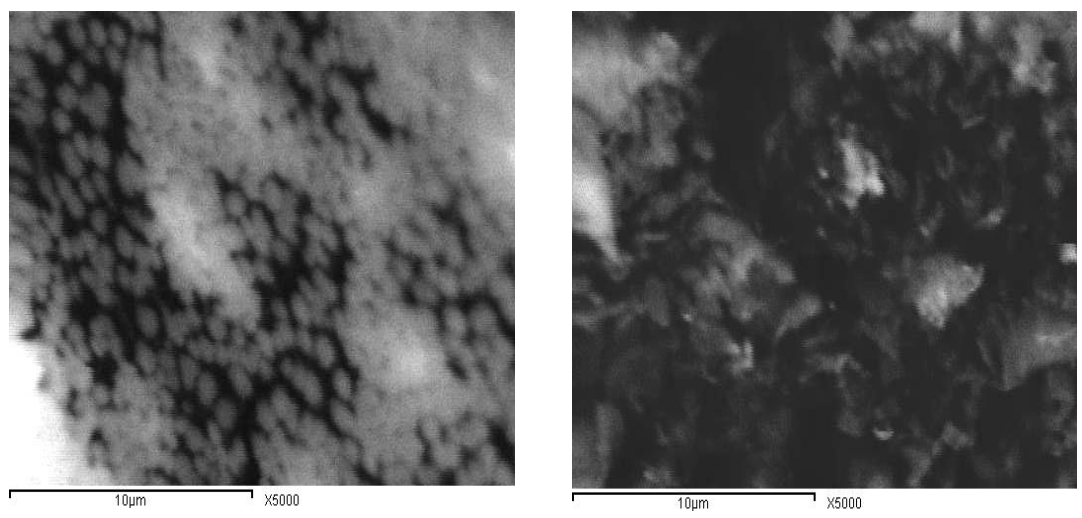

Fig. 7. Scanning electron micrograph of $5 \% \mathrm{Ni} /$ Fig. 8. Scanning electron micrograph of $5 \% \mathrm{Ni} /$ $\mathrm{Al}_{2} \mathrm{O}_{3}$ before addition of p-nitrophenol.
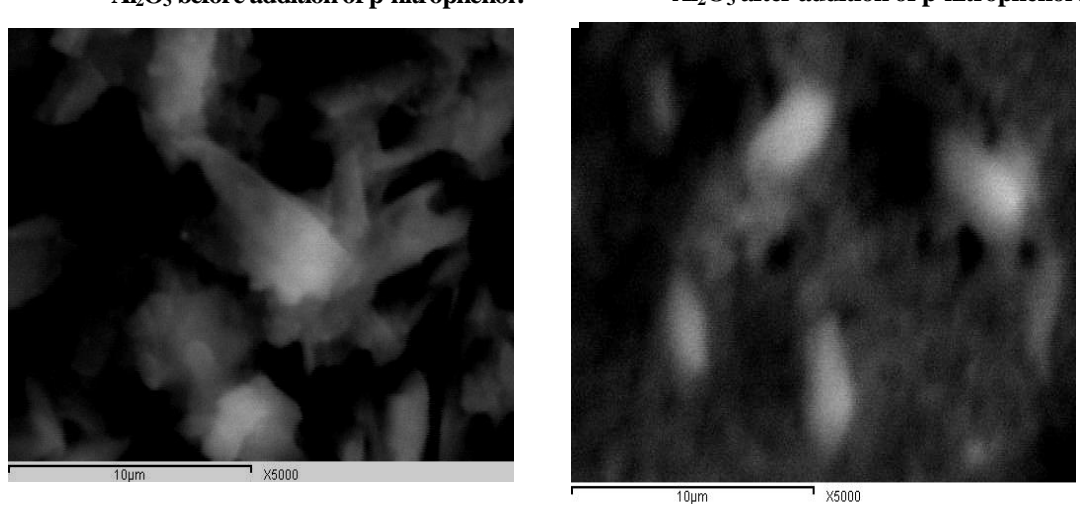

Fig. 9. Scanning electron micrograph of 5\% Ni / Fig. 10. Scanning electron micrograph of 5\% $\mathrm{Ni} /$ $\mathrm{TiO}_{2}$ before addition of $\mathrm{p}$-nitrophen $\mathrm{TiO}_{2}$ after addition of p-nitrophenol
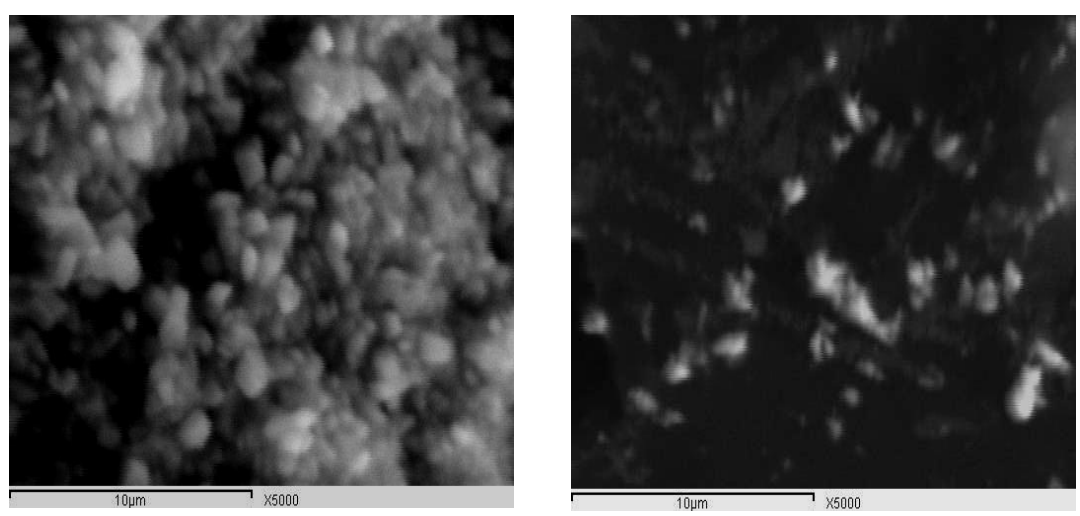

Fig. 11. Scanning electron micrograph of $5 \% \mathrm{Ni} /$ Fig. 12. Scanning electron micrograph of $5 \% \mathrm{Ni} /$ $\mathrm{SiO}_{2}$ before addition of p-nitrophenol . $\mathrm{SiO}_{2}$ after addition of p-nitrophenol.

Egypt. J. Chem. 57, No. 1 (2014) 
To the reduced nickel, $0.5 \mathrm{~g}$ p-nitrophenol in $5 \mathrm{ml}$ methanol was added. $10 \mathrm{ml}$ of hydrazine hydrate and few drops of conc. $\mathrm{NaOH}$ were introduced to the mixture with heating at $80{ }^{\circ} \mathrm{C}$. The mixture was stirred until the color of the solution converted from yellow to colorless, indicating complete conversion of p-nitrophenol into p-aminophenol. The time for complete conversion was taken as a measure of the catalytic activity of the catalyst used.

\section{Reduction of p-nitrophenol on $2.5 \% \mathrm{Ni}$}

The reaction of reduction of p-nitrophenol to p-aminophenol was conducted on all catalysts containing $2.5 \% \mathrm{Ni}$ on different supports. The data are included in the following table:

TABLE 2. The time taken for complete reduction to $\mathrm{p}$-aminophenol with $0.5 \mathrm{~g} \mathrm{p}$ nitrophenol in each experiment .

\begin{tabular}{|c|c|c|c|c|c|c|c|c|c|c|c|c|c|c|c|}
\hline Support & $\begin{array}{c}\text { No.of } \\
\text { repetitions }\end{array}$ & 1 & 2 & 3 & 4 & 5 & 6 & 7 & 8 & 9 & 10 & 11 & 12 & 13 & 14 \\
\hline \multicolumn{2}{|l|}{ Titania } & 17 & 23 & 23 & 24 & 25 & 27 & 29 & 29 & 30 & 30 & 39 & 54 & 63 & 64 \\
\hline \multicolumn{2}{|l|}{ Silica } & 60 & 65 & 70 & 75 & 75 & 80 & 85 & 85 & 88 & & & & & \\
\hline \multicolumn{2}{|c|}{ Alumina } & 43 & 97 & 146 & 170 & 200 & 215 & 230 & 240 & & & & & & \\
\hline \multicolumn{2}{|c|}{ Calcium carbonate } & 14 & 15 & 20 & 27 & 39 & 53 & 58 & 80 & & & & & & \\
\hline \multicolumn{2}{|c|}{ Unsupported $\mathrm{Ni}$} & 85 & 300 & 360 & 440 & 632 & & & & & & & & & \\
\hline
\end{tabular}

From this table, it can be noted that, the nickel catalyst takes $85 \mathrm{sec}$. in the first experiment. This time increases to $300 \mathrm{sec}$ for the second experiment while the $5^{\text {th }}$ experiment takes more than $600 \mathrm{sec}$. On the other hand, $2.5 \% \mathrm{Ni} / \mathrm{TiO}_{2}$ completed the reduction in the first experiment within $23 \mathrm{sec}$. The time for complete reduction on this catalyst was found to increase gradually up to $25 \mathrm{sec}$. for the $5^{\text {th }}$ experiment. Further performing catalysis on this catalyst high stability and durability even up to the $14^{\text {th }}$ experiment which needs $64 \mathrm{sec}$. 
$2.5 \% \mathrm{Ni} / \mathrm{CaCO}_{3}$ showed also high catalytic activity with respect to reduction of p-nitrophenol to p-aminophenol but less than $2.5 \% \mathrm{Ni} / \mathrm{TiO}_{2}$, i.e , the $8^{\text {th }}$ experiment in case of $\mathrm{Ni} / \mathrm{CaCO}_{3}$ needs 80 sec., while for $\mathrm{Ni} / \mathrm{TiO}_{2}$ it needs about $30 \mathrm{sec}$.

The activity and durability of $2.5 \% \mathrm{Ni} / \mathrm{SiO}_{2}$ was found to be stable at about $75 \mathrm{sec}$. from the first up to the $8^{\text {th }}$ experiment.

Dealing with the conversion of p-nitrophenol to p-aminophenol on $2.5 \%$ $\mathrm{Ni} / \mathrm{Al}_{2} \mathrm{O}_{3}$, the conversion takes $43 \mathrm{sec}$. for the first experiment but for the $8^{\text {th }}$ experiment, it takes $200 \mathrm{sec}$.

This means that, the most active and durable catalyst is $2.5 \% \mathrm{Ni} / \mathrm{TiO}_{2}$, and the most inactive one is the unsupported one (Fig 13).

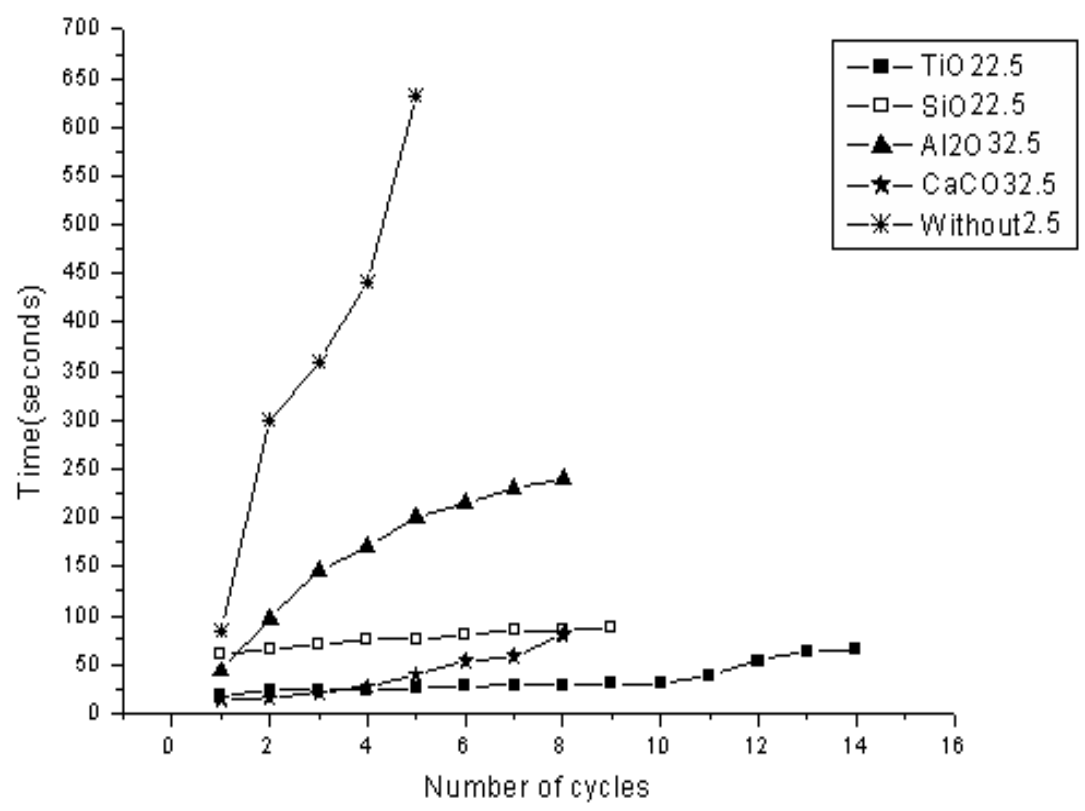

Fig. 13. $2.5 \%$ Supported catalyst.

Reduction of p-nitrophenol with $5 \% \mathrm{Ni} /$ support

This series was done with $5 \% \mathrm{Ni}$ on all supports. The time for complete conversion of p-nitrophenol into p-aminophenol was taken for all catalysts and included in the following table;

Egypt. J. Chem. 57, No. 1 (2014) 
TABLE 3. The time taken for complete reduction of p-nitrophenol to p-aminophenol for $5 \% \mathrm{Ni} /$ different supports.

\begin{tabular}{|l|c|c|c|c|c|c|c|c|c|c|c|c|c|c|c|}
\hline Support & $\begin{array}{c}\text { No. of } \\
\text { repetitions }\end{array}$ & $\mathbf{1}$ & $\mathbf{2}$ & $\mathbf{3}$ & $\mathbf{4}$ & $\mathbf{5}$ & $\mathbf{6}$ & $\mathbf{7}$ & $\mathbf{8}$ & $\mathbf{9}$ & $\mathbf{1 0}$ & $\mathbf{1 1}$ & $\mathbf{1 2}$ & $\mathbf{1 3}$ & $\mathbf{1 4}$ \\
\hline Titania & 35 & 35 & 37 & 38 & 39 & 40 & 42 & 45 & 47 & 50 & 50 & 52 & 54 & $;$ \\
\hline Silica & 55 & 60 & 60 & 70 & 80 & 85 & 90 & 90 & & & & & \\
\hline Alumina & 60 & 90 & 110 & 140 & 150 & 160 & 165 & 165 & & & & & \\
\hline Calcium carbonate & 11 & 12 & 15 & 24 & 36 & 43 & 48 & 64 & 80 & & & & & \\
\hline Unsupported Ni & 120 & 130 & 136 & 140 & & & & & & & & & \\
\hline
\end{tabular}

From the above table it can be observed that for $5 \% \mathrm{Ni} / \mathrm{TiO}_{2}$, the time taken for the first experiment $35 \mathrm{sec}$. and the $14^{\text {th }}$ experiment took about $40 \mathrm{sec}$.. This indicates that this catalyst is durable, i.e. a very small change in its activity was monitored.

The lowest activity in reduction of p-nitrophenol into p-aminophenol was measured for Ni-catalyst without support, i.e. , the first experiment takes $120 \mathrm{sec}$. and the $4^{\text {th }}$ experiment takes $140 \mathrm{sec}$.

Inspecting the obtained results for the catalysts containing $5 \% \mathrm{Ni}$, it can be concluded that the $\mathrm{Ni} / \mathrm{TiO}_{2}$ was the most activeand durable one among all catalysts. On the other hand, unsupported Ni catalyst showed the lowest activity in the reduction of p-nitrophenol into p-aminophenol.

In case of $5 \% \mathrm{Ni} / \mathrm{SiO}_{2}$ this catalyst showed less activity than $5 \% \mathrm{Ni} / \mathrm{TiO}_{2}$ with moderate durability.

$5 \% \mathrm{Ni} / \mathrm{CaCO}_{3}$ started with high catalytic activity, i.e., the complete conversion of p-nitrophenol takes about $11 \mathrm{sec}$. but at the $4^{\text {th }}$ experiment it takes $24 \mathrm{sec}$. while further conductivity experiments up to the $9^{\text {th }}$ one it takes $80 \mathrm{sec}$., i.e. a considerable drop in the activity .

$5 \% \mathrm{Ni} / \mathrm{Al}_{2} \mathrm{O}_{3}$ showed the least activity and durability for p-nitrophenol reduction.

This indicates that the highly active catalyst is the more basic one and the less active catalyst is the more acidic one (Fig. 14). 


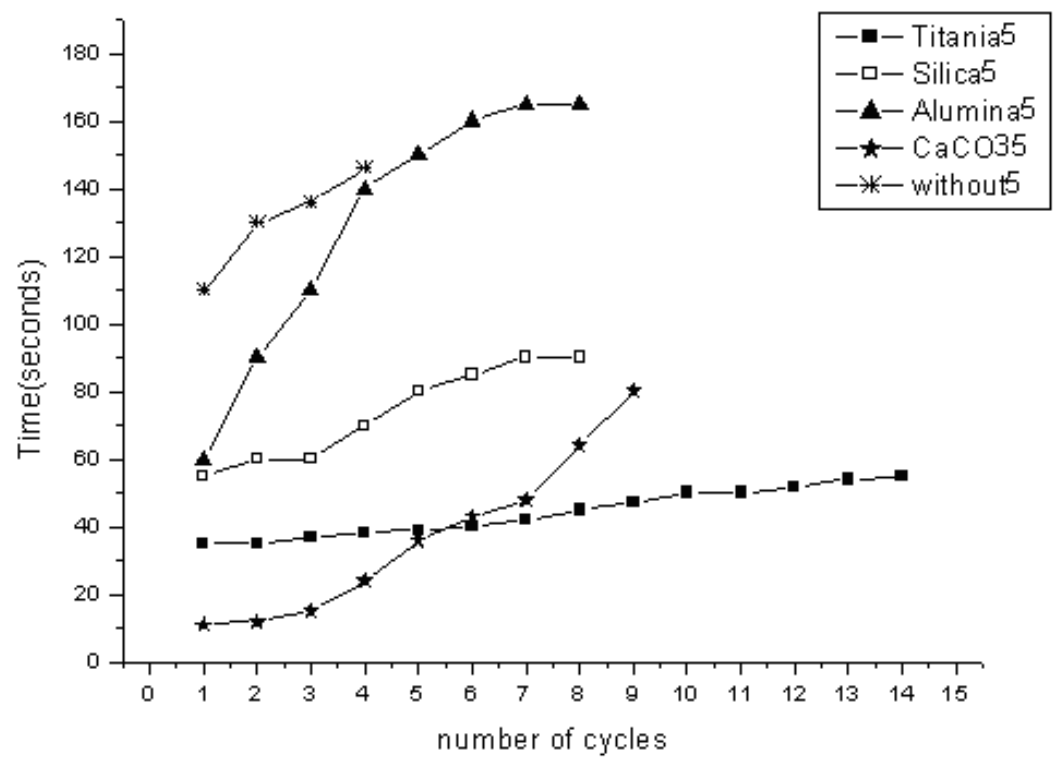

Fig. 14. 5\% Supported catalyst .

Catalytic activity of $10 \% \mathrm{Ni} /$ supports

This series was done with $10 \% \mathrm{Ni}$ on all supports. The time for complete conversion of p-nitrophenol into p-aminophenol was taken for all catalysts and included in the following table:

TABLE 4. The time taken for complete reduction of p-nitrophenol to p-aminophenol for $5 \% \mathrm{Ni} /$ different supports.

\begin{tabular}{|l|c|c|c|c|c|c|c|c|c|c|c|}
\hline Support & $\begin{array}{c}\text { No. of } \\
\text { repetitions }\end{array}$ & $\mathbf{1}$ & $\mathbf{2}$ & $\mathbf{3}$ & $\mathbf{4}$ & $\mathbf{5}$ & $\mathbf{6}$ & $\mathbf{7}$ & $\mathbf{8}$ & $\mathbf{9}$ & $\mathbf{1 0}$ \\
\hline Titania & 19 & 20 & 25 & 30 & 30 & 35 & 37 & 37 & 40 & 40 \\
\hline Silica & 40 & 42 & 42 & 44 & 46 & 53 & 55 & 55 & 67 & \\
\hline Alumina & 30 & 74 & 104 & 113 & 116 & 120 & 124 & 125 & & \\
\hline Calcium carbonate & 13 & 16 & 20 & 36 & 53 & 61 & 71 & 76 & 95 & \\
\hline Without support & 78 & 110 & 130 & 140 & 162 & 180 & 210 & & & \\
\hline
\end{tabular}

From Table 4, it can be observed that $10 \% \mathrm{Ni} / \mathrm{TiO}_{2}$ is the most active and durable one, while $10 \% \mathrm{Ni} / \mathrm{Al}_{2} \mathrm{O}_{3}$ is the lowest active and durable one. On the 
other hand, unsupported Ni-catalyst has very small activity in comparison with all catalysts containing supports (Fig-15).

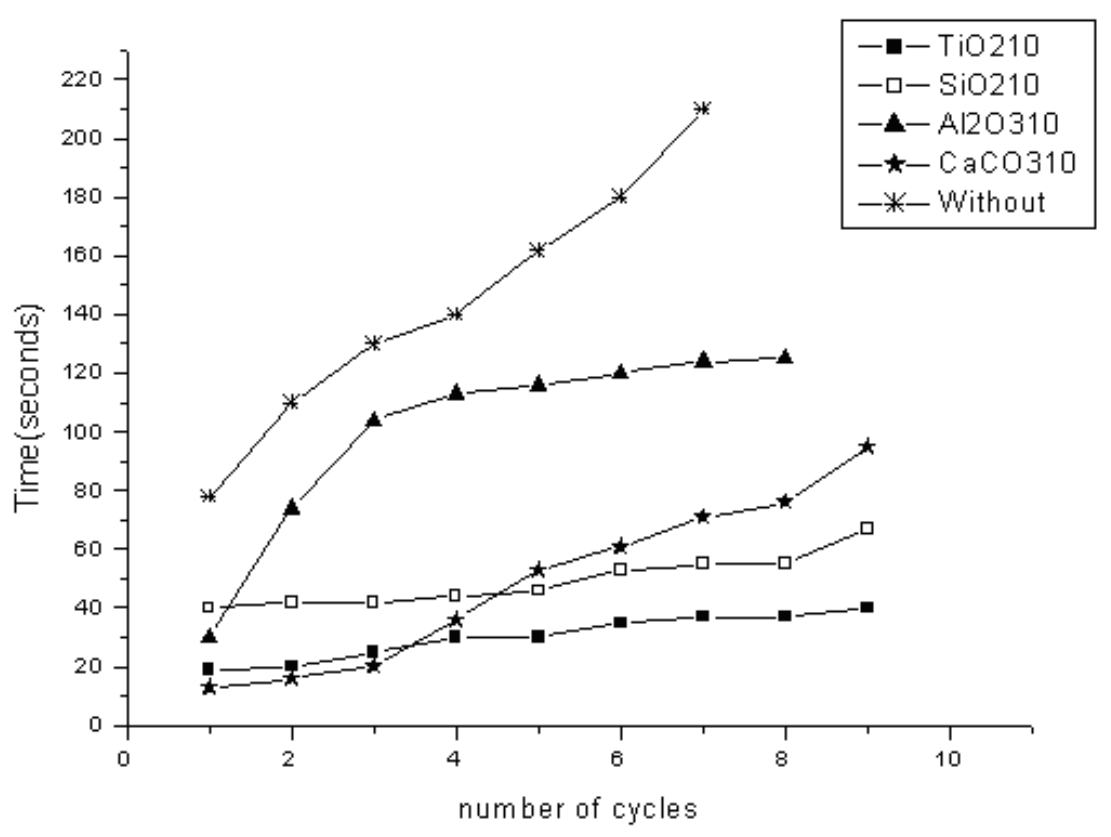

Fig. 15. 10\% Supported catalyst .

One step reaction with $4 \mathrm{~g}$ p-nitrophenol

a- Reduction of p-nitrophenol with $2.5 \% \mathrm{Ni} /$ support

TABLE 5. The results of reduction of $4 \mathrm{~g}$ p-nitrophenol with $\mathrm{Ni} /$ supports.

\begin{tabular}{|l|c|}
\hline Support & Time taken for complete reduction of $\mathbf{4} \mathbf{g}$ p-nitrophenol \\
\hline $\mathrm{TiO}_{2}$ & 150 seconds \\
\hline $\mathrm{SiO}_{2}$ & 340 seconds \\
\hline $\mathrm{Al}_{2} \mathrm{O}_{3}$ & 365 seconds \\
\hline $\mathrm{CaCO}_{3}$ & 125 seconds \\
\hline without & 510 seconds \\
\hline
\end{tabular}

Comparing these results with the obtained above when the reaction proceeded stepwise with $0.5 \mathrm{~g}$ p-nitrophenol in each experiment (Table 6). From these two series, it can be concluded that the one-step reduction is more favorable than stepwise process. The results for all catalysts with $2.5 \% \mathrm{Ni}$ are included in the following table: 
TABLE 6. The results of stepwise and one-step processes reduction of $4 \mathrm{~g} p$ nitrophenol with $2.5 \% \mathrm{Ni} /$ supports.

\begin{tabular}{|l|c|c|}
\hline \multicolumn{1}{|c|}{ Catalyst } & $\begin{array}{c}\text { Stepwise reduction of } \mathbf{4} \text { g p- } \\
\text { nitrophenol }\end{array}$ & One-step reduction \\
\hline $2.5 \% \mathrm{Ni} / \mathrm{TiO}_{2}$ & 197 seconds & 150 seconds \\
\hline $2.5 \% \mathrm{Ni} / \mathrm{SiO}_{2}$ & 683 seconds & 340 seconds \\
\hline $2.5 \% \mathrm{Ni} / \mathrm{Al}_{2} \mathrm{O}_{3}$ & 1341 seconds & 365 seconds \\
\hline $2.5 \% \mathrm{Ni} / \mathrm{CaCO}_{3}$ & 306 seconds & 125 seconds \\
\hline $\mathrm{Ni}$ without support & 1817 seconds & 510 seconds \\
\hline
\end{tabular}

From this table it can be observed that all catalysts showed higher catalytic activity for the one-step process than the stepwise reduction, i.e. the last process for reduction of $5 \mathrm{~g}$ p-nitrophenol needs more time for complete reduction.

The results obtained for catalysts containing $5 \%$ and $10 \% \mathrm{Ni} /$ supports for one-step and stepwise are included in Tables 7 and 8, respectively.

TABLE 7. The results of stepwise and one-step processes reduction of $4 \mathrm{~g} p$ nitrophenol with $5 \% \mathrm{Ni} /$ supports.

\begin{tabular}{|l|c|c|}
\hline Catalyst & $\begin{array}{c}\text { Stepwise reduction of } 4 \text { g p- } \\
\text { nitrophenol }\end{array}$ & One- step reduction \\
\hline $5 \% \mathrm{Ni} / \mathrm{TiO}_{2}$ & 311 seconds & 100 seconds \\
\hline $5 \% \mathrm{Ni} / \mathrm{SiO}_{2}$ & 590 seconds & 220 seconds \\
\hline $5 \% \mathrm{Ni} / \mathrm{Al}_{2} \mathrm{O}_{3}$ & 1040 seconds & 160 seconds \\
\hline $5 \% \mathrm{Ni} / \mathrm{CaCO}_{3}$ & 333 seconds & 110 seconds \\
\hline $\mathrm{Ni}$ without support & 1200 seconds & 470 seconds \\
\hline
\end{tabular}

TABLE 8. The results of stepwise and one-step processes reduction of $4 \mathrm{~g}$ p-nitrophenol with $10 \% \mathrm{Ni} /$ supports.

\begin{tabular}{|l|c|c|}
\hline Catalyst & $\begin{array}{c}\text { Stepwise reduction of } \mathbf{4} \text { g p- } \\
\text { nitrophenol }\end{array}$ & One-step reduction \\
\hline $10 \% \mathrm{Ni} / \mathrm{TiO}_{2}$ & 160 seconds & 33 seconds \\
\hline $10 \% \mathrm{Ni} / \mathrm{SiO}_{2}$ & 180 seconds & 435 seconds \\
\hline $10 \% \mathrm{Ni} / \mathrm{Al}_{2} \mathrm{O}_{3}$ & 630 seconds & 106 seconds \\
\hline $10 \% \mathrm{Ni} / \mathrm{CaCO}_{3}$ & 105 seconds & 40 seconds \\
\hline $\mathrm{Ni}$ without support & 650 seconds & 300 seconds \\
\hline
\end{tabular}

It can be seen from Tables 7, 8 and 9 that the one-step reduction of a certain amount of p-nitrophenol is more efficient than the stepwise reduction process.

\section{Conclusions}

The supported Ni nanoparticle catalyst was prepared by the impregnation method using hydrazine hydrate as a reductant. For the supported Ni catalysts, support property has an important impact on the catalytic activity in pnitrophenol reduction to p-aminophenol. The catalytic activity increased with the

Egypt. J. Chem. 57, No. 1 (2014) 
increase of the reduced metallic $\mathrm{Ni}$ amount and followed the order of $\mathrm{Ni} / \mathrm{TiO}_{2}>\mathrm{Ni} /$ $\mathrm{CaCO}_{3} \gg \mathrm{Ni} / \mathrm{SiO}_{2}>\mathrm{Ni} / \mathrm{Al}_{2} \mathrm{O}_{3}>$ Unsupported nickel. XRD patterns showed that $5 \% \mathrm{Ni} / \mathrm{SiO}_{2}$ catalyst has a well crystalline $\mathrm{Ni}$ metal phase while after using the catalyst nearly no crystalline $\mathrm{Ni}$ could be observed. In contrast to $\mathrm{SiO}_{2}$-supported catalyst, the crystallinity of $\mathrm{Ni} / \mathrm{Al}_{2} \mathrm{O}_{3}, \mathrm{Ni} / \mathrm{TiO}_{2}$ and $\mathrm{Ni} / \mathrm{CaCO}_{3}$ showed very small change after using the catalyst under the same conditions (Fig. 1-4) which can be attributed to the strong metal support interaction between $\mathrm{Ni}$ metal and $\mathrm{Al}_{2} \mathrm{O}_{3}$, $\mathrm{TiO}_{2}$ and $\mathrm{CaCO}_{3}$ supports, respectively compared to weak metal support interaction between $\mathrm{Ni}$ and $\mathrm{SiO}_{2}$ support. XRD patterns of $2.5 \mathrm{wt} \% \mathrm{Ni} / \mathrm{SiO}_{2}$, $\mathrm{Ni} / \mathrm{TiO}_{2}, \mathrm{Ni} / \mathrm{CaCO}_{3}$ and $\mathrm{Ni} / \mathrm{Al}_{2} \mathrm{O}_{3}$ catalysts showed no crystalline $\mathrm{Ni}$ metal at all which is attributed to the very small amount of Ni loaded. One-step reduction of p-nitrophenol is better than stepwise process for the same quantity of $\mathrm{p}$ nitrophenol.

\section{References}

1. Rode, C.V., Vaidya, M.J. and Chaudhari, R.V., Synthesis of $p$-aminophenol by catalytic hydrogenation of nitrobenzene. Org. Process Res. Dev. 3, 465 (1999).

2. Rode, C.V., Vaidya, M.J., Jaganathan, R. and Chaudhari, R.V., Hydrogenation of nitrobenzene to $p$-aminophenol in a four-phase reactor: Reaction kinetics and mass transfer effects. Chem. Eng. Sci. 56, 1299 (2001).

3. Du, Y., Chen, H.L., Chen, R.Z. and Xu, N.P., Synthesis of p-aminophenol from pnitrophenol over nano-sized nickel catalysts. Appl. Catal. A :Gen. 277, 259 (2004).

4. Diskin, A.M., Cunningham, R.H. and Ormerod, R.M., The oxidative chemistry of methane over supported nickel catalysts . Catal. Today, 46 (2/3), 147 (1998)

5. Nagaoka, K., Sato, K., Nishiguchi, H. and Takita, Y., Influence of support on catalytic behavior of nickel catalysts in oxidative steam prereforming of $\mathrm{n}$-butane for fuel cell applications. Appl. Catal. A: Gen. 327,139 (2007).

6. de Haan, R., Joorst, G., Mokoena, E. and Nicolaides, C.P., Non-sulfided nickel supported on silicated alumina as catalyst for the hydrocracking of n-hexadecane and of iron-based Fischer-Tropsch wax. Appl. Catal. A: Gen. 327, 247 (2007).

7. Sathe, S.S., Process for preparing p-aminophenol in the presence of dimethyldodecylamine sulfate. US Pat., 4, 1761, 38( 1979).

8. Lee, L.T., Chen, M.H. and Yao, C.N., Process for manufacturing p-aminophenol. US Pat. 4885389 ( 1989).

9. Yun, K.S. and Cho, B.W., Process for preparing paraaminophenol. US Pat. 066369 (1991).

10. Du, Y., Chen, H.L., Chen, R.Z. and Xu, N.P., Synthesis of p-aminophenol from pnitrophenol over nano-sized nickel catalysts. Appl. Catal. A: Gen. 277, 259264(2004). 
11.Quincoces, C.E. and Gonzfilez, M.G., Kinetic study on $\mathrm{CO}_{2}$ reforming of methane . Chin. J. Chem. ling, 9, 190- 195(2001).

12. Selim, M.M. and Abd EI-Maksoud, I.H., Spectroscopic and catalytic characterization of Ni nano-size catalyst for edible oil hydrogenation. Microporous and Mesoporous Materials, 85 (3,7) 273-278 November (2005).

13. Selim, M.M. and Fathy, N.A., Factors affecting the catalytic activity of nano nickel in hydrogenation of para nitrophenol. Egyp. J. Chemistry accepted (2013).

14. Haiam H. Ibraheem, Doaa M. El-Mekkawi, Hassan, S.A. and Selim, M.M., Innovative method for the reduction of nitrophenols using nickel nanocatalysts supported on zeolite-Y prepared from Egyptian kaolin. Egypt. J. Chemistry, 53 (4) 565 (2010).

15. Selim, M.M., Abd El Maksoud, I.H. and Saleh, T.S., The use of nano nickel catalyst in reduction of P-nitrophenol using hydrazine hydrate as hydrogen donor. Egyp. J. Chem 52 (4) 491 (2009).

16. Selim, M.M., Abd El Maksoud, I.H. and Saleh, T., Egyptian Patent, 24867 (2010).

(Received 4/ 3/ 2014;

accepted 11/3/2014)

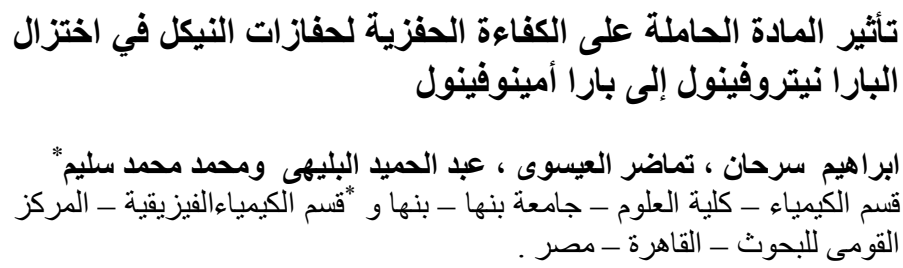

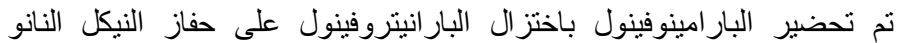

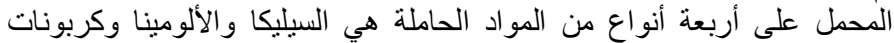

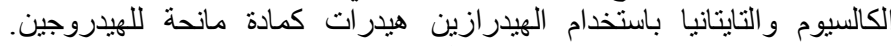

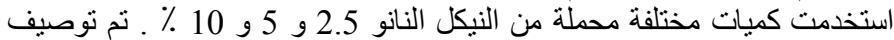

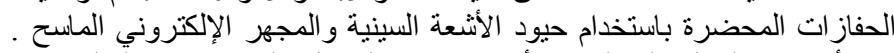

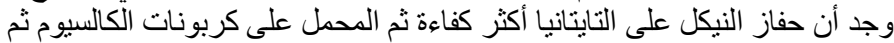

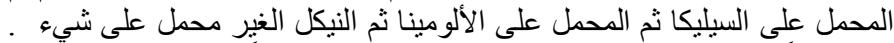

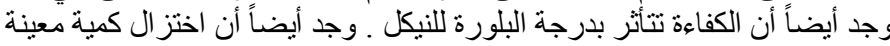

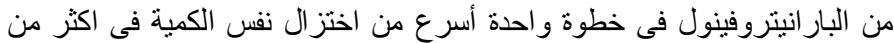

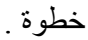

Egypt. J. Chem. 57, No. 1 (2014) 